\title{
Yellow Rust Resistance in Advanced Lines and Commercial Cultivars of Bread Wheat from Ethiopia
}

\author{
Ayele Badebo' ${ }^{*}$, Solomon Assefa ${ }^{1}$ and H. Fehrmann ${ }^{2}$ \\ ${ }^{1}$ Ethiopian Institute of Agricultural Research, P O Box 2003 Addis Ababa, Ethiopia \\ 2Institute of Plant Pathology and Plant Protection, Grisebachstr. 6, 37077 Goettingen, Germany
}

\begin{abstract}
Bread wheat (Triticum aestivum L.) cultivars often succumb to yellow rust (Puccinia strïformis f.sp. tritici Westend.) soon after their release for commercial production, especially in the highlands of south-eastern Ethiopia. Variety diversification may buffer the ever evolving new races of the yellow rust pathogen. The objective of this study was to characterize seedling yellow rust resistance in 21 advanced bread wheat lines and 20 cultivars from Ethiopia. Yellow rust infection types (ITs) produced on test wheat lines and cultivars from nine yellow rust races were compared with ITs produced on standard differential lines that differed for specific yellow rust resistance genes. The experiment was conducted at seedling stage under greenhouse conditions in Goettingen, Germany during 2001. The result indicated that most of the advanced bread wheat lines possess different yellow rust resistance genes when compared to the commercial cultivars. Seedling genes $Y r 1, Y r 2, Y r 3 V, Y r 4$, $Y r 6$ and $Y r 17$ with or without $Y r 9$ were postulated to be present in 11 advanced lines. However, only $Y r 7$ and $Y r 9$ were postulated to be present in five of the commercial bread wheat cultivars. The newly identified resistance sources could be of great importance for enhancing the genetic base of resistance of bread wheat to yellow rust in Ethiopia.
\end{abstract}

Keywords: Race; Resistance Gene; Virulence; Yellow or Stripe Rust

\section{Introduction}

Yellow or stripe rust (Puccinia striiformis f.sp. tritici Westend) is a major wheat disease in the highlands of Ethiopia. It was first reported in the early 1940s, but gained importance with the expansion of high-yielding, semi-dwarf bread wheat cultivars in the mid 1980s (Hailu, 1991). Yellow rust infects the leaf, leaf sheath and spikes of the wheat plant; it can cause yield losses of $96 \%$ depending on the susceptibility of the cultivars and environmental conditions (Eshetu, 1986).

Wheat researchers in Ethiopia have been continuously breeding for disease resistance, wide adaptability and high yield, which resulted in the release of many cultivars to farmers. However, most of these cultivars were abandoned from production due to their susceptibility mainly to yellow rust disease (Ayele and Stubbs, 1995). The main reasons for periodic outbreaks of yellow rust disease in Ethiopia are the scarce information on the genetic variation of host-pathogen interactions and unreliability of current sources of resistance to the prevailing race population (Ayele, 2002). Wheat cultivars with high levels of race-specific yellow rust resistance often select virulent races, which result in loss of resistance in these cultivars.

So far, more than 37 yellow rust resistance genes have been reported worldwide and most of these confer seedling resistances (http://www.wheat.pw.usda.gov.). However, virulence genes of the pathogen which overcome many of the seedling resistance genes had already been detected individually or in many combinations (Stubbs, 1988).
In general, research on yellow rust disease should supply wheat genotypes with combinations of effective genes for resistance to the prevailing races of the pathogen.

The gene-for-gene concept (Flor, 1971) is often applied to determine the probable identity of seedling rust resistance genes in wheat cultivars (Wellings et al., 1988; Ayele et al., 1990). Although the sexual stage of the yellow rust fungus has not yet been identified, the race specific yellow rust resistance genes apparently are assumed to conform to the gene- for- gene system (Zadoks, 1961). The low and high ITs produced by a diverse group of yellow rust races on lines under study are compared with ITs produced by the races on yellow rust differential lines that differ for specific resistance genes. Yellow rust races that produce distinct ITs on specific yellow rust resistance genes in the differential line will also produce similar ITs to those cultivars that have the same resistance genes.

In this paper, we report on the yellow rust resistance spectra of advanced bread wheat lines and commercial cultivars from Ethiopia with regard to nine different races at seedling stage.

\section{Materials and Methods \\ 2.1. Yellow Rust Isolates}

Two yellow rust isolates from Ethiopia and seven from Germany were used in this study. The isolates from Germany were obtained from Biologische Bundesanstalt für Land und Forstwirtschaft, Braunschweig while the isolates from Ethiopia had originally been collected from southeastern Ethiopia during 1998/99. A mono-pustule was prepared for each isolate and multiplied on the susceptible bread wheat cultivar, 'Morocco', and analyzed

*Corresponding author. E-mail: ayele88@yahoo.com or DZARC@ethionet.et

CHaramaya University, 2008 ISSN 1992-0407 
Ayele $e t$ al.

on the standard differential sets according to Johnson et al. (1972).

\subsection{Differential Lines}

A total of 21 yellow rust standard differential lines obtained from IPO, Wageningen, The Netherlands were used to characterize the nine yellow rust isolates (Table 1). The 'world-set' and the 'European set' each comprised eight differential lines (Stubbs, 1985). Moreover, Kema
East African Journal of Sciences Volume 2 (1) 29-34

and Lange (1992) proposed incorporating Yr15 in the differential set of cultivars through extension of the 'world set', and a similar suggestion for Yr5 by Wellings \& McIntosh (1990) was adopted here. In addition, Stubbs (1988) suggested Kalyansona (Yr2) and Federation *4/Kavkaz (Yr9) and Bariana and McIntosh (1994) proposed another differential cultivar, VPM1 ( $Y r 17)$ to be included as supplemental differential sets for yellow rust.

Table 1. Origin of nine yellow rust races and their resistance factors, which were used to study the resistance spectra of advanced bread wheat lines and commercial cultivars.

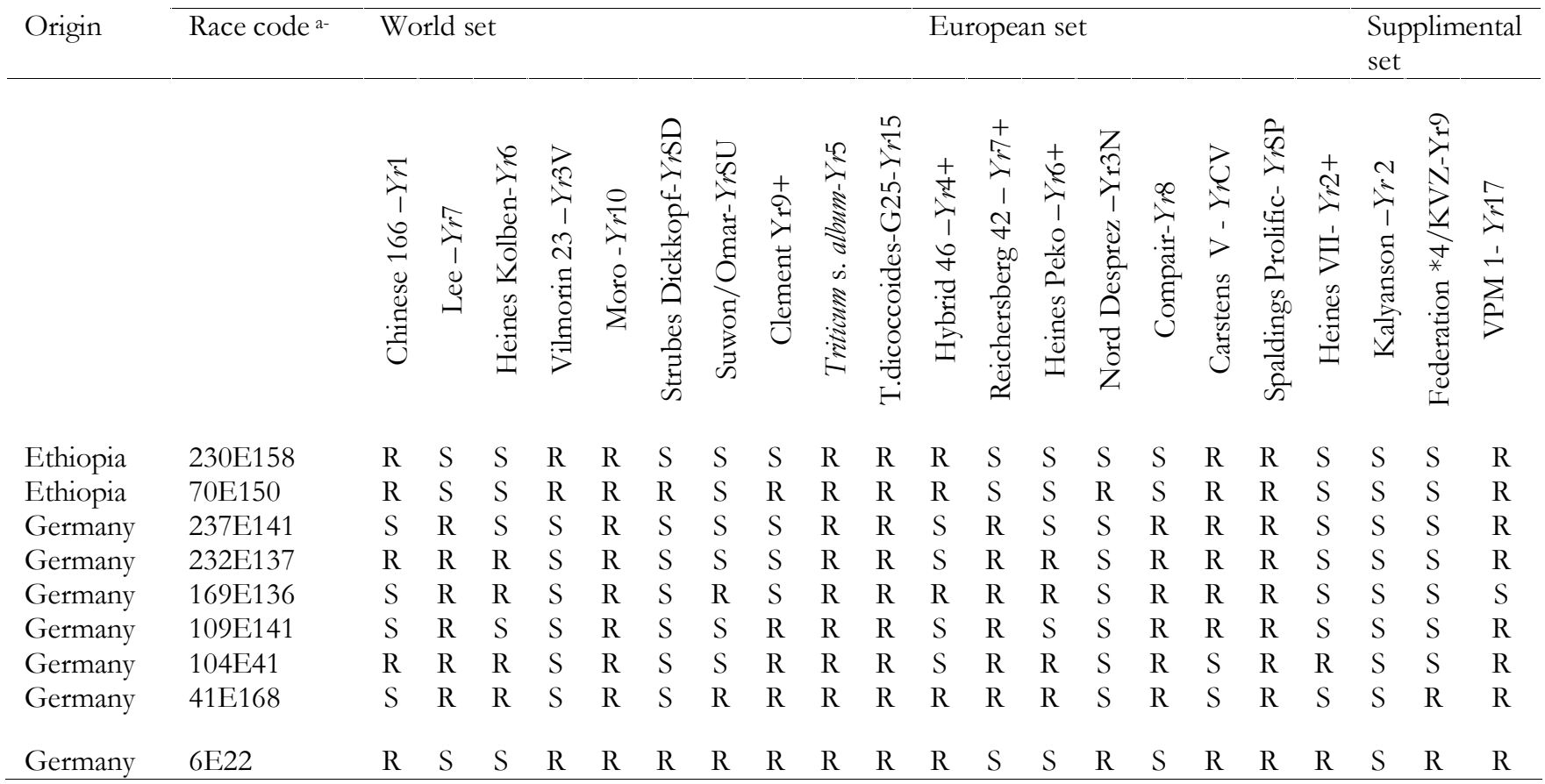

${ }^{a}$ Nomenclature according to Johnson et al. (1972).

${ }^{b} \mathrm{~S}=$ Virulence, $\mathrm{R}=$ Avirulence on differential lines

\subsection{Wheat Genotypes}

Twenty-one advanced bread wheat lines and 20 commercial cultivars were used in this study (Table 2). The advanced bread wheat lines were developed through a shuttle breeding program between the Institute of Plant Pathology and Plant Protection, Goettingen, Germany and Kulumsa Research Center, Ethiopia (Solomon, 2001). The commercial cultivars were obtained from the national bread wheat breeding program at Kulumsa. The wheat genotypes and yellow rust differential lines were simultaneously tested to nine individual yellow rust isolates. The experiment was conducted in the Institute of Plant Pathology and Plant Protection, Goettingen, Germany during 2001.

\subsection{Testing Procedures}

From each entry, $7-8$ seeds were sown in $5 \mathrm{~cm}^{3}$ jiffy pots that contained a mixture of soil, sand, and compost at the ratio of 1:1:1 v/v/v/ in the greenhouse. Seedling tests were conducted according to Stubbs (1985). About a week old seedlings with fully expanded first leaves were sprayed with a suspension of yellow rust spores with a concentration of $10^{5}-10^{6} / \mathrm{ml}$ in mineral oil (FC-40, 3M Fluorinert Electronic liquid, Saint Paul, USA) onto the leaves. The treated seedlings were incubated for 24 hours in plastic cages at $c a .10^{\circ} \mathrm{C}$ and $100 \%$ relative humidity. Thereafter, the seedlings were transferred to a growth chamber to allow symptom development. Inside the chamber, the day/night regime was $16 \mathrm{hrs}$ of light $(18,000$ $\mathrm{lx})$ and $8 \mathrm{hrs}$ darkness at $16-17^{\circ} \mathrm{C}$, and the relative humidity was $c a .70 \%$. About a week after spraying, $2 \mathrm{~g}$ of fertilizer $\left(\mathrm{N}: \mathrm{P}_{2} \mathrm{O}_{5}: \mathrm{K}_{2} \mathrm{O}=15: 11: 15\right)$ per $100 \mathrm{cc}$ was added to each set of 24 pots, and the second leaves were cut once a week after inoculation to minimize light competition. 

Table 2. The reaction of advanced bread wheat lines and commercial cultivars to nine yellow rust races at seedling stage.

a. Advanced bread wheat lines

\begin{tabular}{|c|c|c|c|c|c|c|c|c|c|c|c|}
\hline No. & Lines & Pedigree & $\begin{array}{l}\infty \\
i n \\
\stackrel{T}{\mid T} \\
0 \\
\stackrel{2}{N}\end{array}$ & 年 & 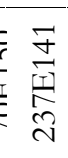 & $\begin{array}{l}\stackrel{N}{m} \\
\stackrel{-I}{N} \\
\approx\end{array}$ & 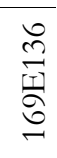 & 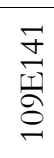 & 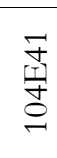 & $\underset{\underset{I}{\rightleftharpoons}}{\underset{\forall}{\rightleftharpoons}}$ & $\begin{array}{l}\text { N } \\
\text { Iิ }\end{array}$ \\
\hline 1 & 8.2 .7 & $\mathrm{Arb} / / 295 / \mathrm{SM} / 3 / 149 / \mathrm{SM} / / 150 / \mathrm{M}$ & $\mathrm{R}^{\mathrm{b}}$ & $\mathrm{R}$ & $\mathrm{S}$ & $\mathrm{R}$ & $\mathrm{S}$ & $\mathrm{S}$ & $\mathrm{R}$ & $\mathrm{R}$ & $\mathrm{R}$ \\
\hline 2 & $8.3 .8(\mathrm{~W})$ & HAR $1709 / 3 / 300 / \mathrm{SM} / / 150 / \mathrm{M}$ & $\mathrm{R}$ & $\mathrm{R}$ & $\mathrm{R}$ & $\mathrm{R}$ & $\mathrm{S}$ & $\mathrm{R}$ & $\mathrm{R}$ & $\mathrm{R}$ & $\mathrm{R}$ \\
\hline 3 & $8.3 .8(\mathrm{~B})$ & HAR $1709 / 3 / 300 / \mathrm{SM} / / 150 / \mathrm{M}$ & $\mathrm{R}$ & $\mathrm{R}$ & $\mathrm{R}$ & $\mathrm{R}$ & $\mathrm{R}$ & $\mathrm{R}$ & $\mathrm{R}$ & $\mathrm{R}$ & $\mathrm{R}$ \\
\hline 4 & 8.3 .11 & ET-13/3/149/SM//150/M & $\mathrm{S}$ & $\mathrm{R}$ & $\mathrm{S}$ & $\mathrm{S}$ & $\mathrm{S}$ & $\mathrm{R}$ & S & $\mathrm{R}$ & $\mathrm{R}$ \\
\hline 5 & $8.3 .12(\mathrm{~T})$ & Kon/3/149/SM//150/M & $\mathrm{S}$ & $\mathrm{S}$ & S & $\mathrm{S}$ & $\mathrm{S}$ & $\mathrm{S}$ & $\mathrm{S}$ & $\mathrm{S}$ & $\mathrm{S}$ \\
\hline 6 & $8.3 .12(\mathrm{~S})$ & Kon/3/149/SM//150/M & $\mathrm{S}$ & $\mathrm{S}$ & $\mathrm{S}$ & $\mathrm{S}$ & $\mathrm{S}$ & $\mathrm{R}$ & $\mathrm{R}$ & $\mathrm{S}$ & $\mathrm{R}$ \\
\hline 7 & 8.3 .13 & HAR1709/3/149/SM//150/M & $\mathrm{S}$ & $\mathrm{S}$ & $\mathrm{S}$ & $\mathrm{R}$ & $\mathrm{S}$ & $\mathrm{R}$ & $\mathrm{S}$ & $\mathrm{S}$ & $\mathrm{S}$ \\
\hline 8 & 11.1.23 & Ton/4/Arb//24/E/3/295/SM//149/M & $\mathrm{R}$ & $\mathrm{R}$ & S & $\mathrm{R}$ & S & $\mathrm{S}$ & $\mathrm{R}$ & $\mathrm{R}$ & $\mathrm{R}$ \\
\hline 9 & 11.4.16-1 & HAR1709/4/Arb//295/SM/3/149/SM//150/M & $\mathrm{S}$ & $\mathrm{R}$ & $\mathrm{S}$ & $\mathrm{R}$ & $\mathrm{R}$ & $\mathrm{R}$ & $\mathrm{R}$ & $\mathrm{R}$ & $\mathrm{R}$ \\
\hline 10 & 11.4.16-2 & HAR 1709/4/Arb//295/SM/3/149/SM//150/M & $\mathrm{R}$ & $\mathrm{R}$ & $\mathrm{S}$ & $\mathrm{R}$ & $\mathrm{R}$ & $\mathrm{R}$ & $\mathrm{R}$ & $\mathrm{R}$ & $\mathrm{R}$ \\
\hline 11 & 11.4.16-3 & HAR 1709/4/Arb//295/SM/3/149/SM//150/M & $\mathrm{R}$ & $\mathrm{R}$ & $\mathrm{R}$ & $\mathrm{R}$ & $\mathrm{S}$ & $\mathrm{R}$ & $\mathrm{R}$ & $\mathrm{R}$ & $\mathrm{R}$ \\
\hline 12 & $11.5 .26-1$ & M/4/HAR1709/3/149/SM//150/M & $\mathrm{R}$ & $\mathrm{R}$ & $\mathrm{S}$ & $\mathrm{R}$ & $\mathrm{R}$ & $\mathrm{R}$ & $\mathrm{R}$ & $\mathrm{R}$ & $\mathrm{R}$ \\
\hline 13 & $11.5 .26-2$ & M/4/HAR1709/3/149/SM//150/M & $\mathrm{S}$ & $\mathrm{S}$ & S & $\mathrm{R}$ & $\mathrm{R}$ & $\mathrm{S}$ & $\mathrm{R}$ & $\mathrm{R}$ & $\mathrm{R}$ \\
\hline 14 & $11.5 .26-3$ & M/4/HAR1709/3/149/SM//150/M & $\mathrm{S}$ & $\mathrm{S}$ & $\mathrm{S}$ & $\mathrm{R}$ & $\mathrm{S}$ & $\mathrm{S}$ & $\mathrm{R}$ & $\mathrm{R}$ & $\mathrm{R}$ \\
\hline 15 & 11.5.32 & T1/Arb/4/Kon/3/149/SM//150/M & $\mathrm{S}$ & $\mathrm{R}$ & S & $\mathrm{R}$ & $\mathrm{R}$ & $\mathrm{S}$ & $\mathrm{S}$ & $\mathrm{R}$ & $\mathrm{R}$ \\
\hline 16 & $11.5 .38-1$ & HAR 1709/4/ET-13/3/149/SM//150/M & $\mathrm{S}$ & $\mathrm{S}$ & S & $\mathrm{R}$ & $\mathrm{S}$ & $\mathrm{R}$ & S & $\mathrm{S}$ & $\mathrm{R}$ \\
\hline 17 & $11.5 .38-2$ & HAR 1709/4/ET-13/3/149/SM//150/M & $\mathrm{S}$ & $\mathrm{S}$ & $\mathrm{S}$ & $\mathrm{R}$ & $\mathrm{S}$ & $\mathrm{R}$ & $\mathrm{S}$ & $\mathrm{S}$ & $\mathrm{S}$ \\
\hline 18 & 11.5.39-1 & HAR 1709/4/Kon/3/149/SM//150/M & $\mathrm{R}$ & $\mathrm{R}$ & $\mathrm{S}$ & $\mathrm{S}$ & $\mathrm{S}$ & $\mathrm{S}$ & $\mathrm{S}$ & $\mathrm{S}$ & $\mathrm{R}$ \\
\hline 19 & 11.5.39-2 & HAR 1709/4/Kon/3/149/SM//150/M & $\mathrm{R}$ & $\mathrm{R}$ & S & $\mathrm{S}$ & $\mathrm{S}$ & $\mathrm{S}$ & $\mathrm{S}$ & $\mathrm{S}$ & $\mathrm{R}$ \\
\hline 20 & 11.6.21 & $\mathrm{M} / 4 / \mathrm{ET} 13 / 3 / \mathrm{EY} 2 / / 2 / \mathrm{E}$ & $\mathrm{R}$ & $\mathrm{R}$ & $\mathrm{S}$ & $\mathrm{S}$ & $\mathrm{S}$ & $\mathrm{S}$ & $\mathrm{S}$ & $\mathrm{S}$ & $\mathrm{R}$ \\
\hline 21 & 11.6.24 & $\mathrm{M} / 4 / \mathrm{HAR} 1709 / 3 / \mathrm{M} / / 24 / \mathrm{E}$ & $\mathrm{R}$ & $\mathrm{R}$ & $\mathrm{R}$ & $\mathrm{R}$ & $\mathrm{S}$ & $\mathrm{R}$ & $\mathrm{R}$ & $\mathrm{R}$ & $\mathrm{R}$ \\
\hline \multicolumn{12}{|c|}{ b. Commercial cultivars } \\
\hline 1 & HAR1899 & Cook/Vee/Dov/Seri/3/Bjy/Coc & $\mathrm{S}$ & S & S & S & $\mathrm{R}$ & $\mathrm{S}$ & $\mathrm{S}$ & $\mathrm{S}$ & $\mathrm{R}$ \\
\hline 2 & HAR1407 & Cook/Vee/Dov/Seri & S & $\mathrm{R}$ & $\mathrm{R}$ & $\mathrm{R}$ & $\mathrm{R}$ & $\mathrm{R}$ & $\mathrm{R}$ & $\mathrm{R}$ & $\mathrm{R}$ \\
\hline 3 & HAR416 & BOW \#28 & S & $\mathrm{R}$ & $\mathrm{R}$ & $\mathrm{R}$ & $\mathrm{R}$ & $\mathrm{R}$ & $\mathrm{R}$ & $\mathrm{R}$ & $\mathrm{R}$ \\
\hline 4 & HAR1775 & ARO Sel 60/89 & S & S & $\mathrm{S}$ & $\mathrm{S}$ & $\mathrm{S}$ & $\mathrm{S}$ & S & $\mathrm{R}$ & $\mathrm{R}$ \\
\hline 5 & HAR1522 & BOW'S / BUC'S & S & S & $\mathrm{R}$ & $\mathrm{S}$ & $\mathrm{R}$ & $\mathrm{R}$ & S & S & $\mathrm{R}$ \\
\hline 6 & HAR1595 & F371/TRM//BUC'S'/3/LIRA'S' & S & $\mathrm{R}$ & $\mathrm{R}$ & $\mathrm{S}$ & $\mathrm{R}$ & $\mathrm{R}$ & $\mathrm{S}$ & $\mathrm{R}$ & $\mathrm{R}$ \\
\hline 7 & HAR1868 & Gov Az//Mus's'/3/R37/Ghl/2/... & S & $\mathrm{R}$ & $\mathrm{S}$ & $\mathrm{R}$ & $\mathrm{R}$ & $\mathrm{R}$ & $\mathrm{R}$ & $\mathrm{R}$ & $\mathrm{R}$ \\
\hline 8 & HAR710 & MRL'S'/BUC'S' & $\mathrm{S}$ & $\mathrm{R}$ & $\mathrm{R}$ & $\mathrm{R}$ & $\mathrm{R}$ & $\mathrm{R}$ & $\mathrm{R}$ & S & $\mathrm{R}$ \\
\hline 9 & HAR1685 & Attila 'S' & $\mathrm{S}$ & $\mathrm{R}$ & $\mathrm{S}$ & $\mathrm{S}$ & $\mathrm{R}$ & $\mathrm{R}$ & $\mathrm{R}$ & $\mathrm{R}$ & $\mathrm{S}$ \\
\hline 10 & HAR604 & $4777(2) / / F K N / G B / 3 / P V N ' S '$ & S & $\mathrm{R}$ & $\mathrm{S}$ & $\mathrm{R}$ & $\mathrm{R}$ & S & $\mathrm{R}$ & $\mathrm{R}$ & S \\
\hline 11 & HAR1709 & BOW 28 X ROMANY B.C. & S & $\mathrm{R}$ & $\mathrm{R}$ & S & $\mathrm{S}$ & S & S & S & $\mathrm{R}$ \\
\hline 12 & BATU & SUN BIRD 4 & $\mathrm{~S}$ & $\mathrm{R}$ & $\mathrm{R}$ & $\mathrm{R}$ & $\mathrm{R}$ & $\mathrm{R}$ & $\mathrm{R}$ & $\mathrm{R}$ & $\mathrm{R}$ \\
\hline 13 & DASHEN & VEE \#17 & S & $\mathrm{R}$ & $\mathrm{R}$ & $\mathrm{R}$ & $\mathrm{R}$ & $\mathrm{R}$ & $\mathrm{R}$ & $\mathrm{R}$ & $\mathrm{R}$ \\
\hline 14 & GARA & BOW'S' & S & $\mathrm{R}$ & $\mathrm{R}$ & $\mathrm{R}$ & $\mathrm{R}$ & $\mathrm{R}$ & $\mathrm{R}$ & $\mathrm{R}$ & $\mathrm{R}$ \\
\hline 15 & HAR407 & VEE \#15 & S & $\mathrm{S}$ & $\mathrm{S}$ & S & $\mathrm{S}$ & $\mathrm{R}$ & S & $\mathrm{R}$ & $\mathrm{R}$ \\
\hline 16 & K6295-4A & ROMANYX GB-GAMENYA & $\mathrm{S}$ & $\mathrm{S}$ & $\mathrm{S}$ & $\mathrm{S}$ & $\mathrm{S}$ & $\mathrm{S}$ & $\mathrm{S}$ & $\mathrm{S}$ & $\mathrm{S}$ \\
\hline 17 & ET13 A2 & UQ105 Sel. X ENKOY) & S & S & $\mathrm{S}$ & $\mathrm{S}$ & $\mathrm{S}$ & $\mathrm{S}$ & S & S & $\mathrm{S}$ \\
\hline 18 & DERESEL. & CI81541//2*FR & S & S & $\mathrm{S}$ & $\mathrm{S}$ & $\mathrm{S}$ & S & $\mathrm{S}$ & $\mathrm{S}$ & $\mathrm{S}$ \\
\hline 19 & K6290-B & AF.MAYOXGEM) XROMANY & S & $\mathrm{S}$ & $\mathrm{S}$ & S & $\mathrm{S}$ & S & $\mathrm{S}$ & S & $\mathrm{S}$ \\
\hline 20 & ENKOY & Heb. Sel./WIS245xSUP51 x (FR-FN/Y) & S & S & $\mathrm{R}$ & $\mathrm{R}$ & $\mathrm{S}$ & S & $\mathrm{S}$ & $\mathrm{S}$ & $\mathrm{R}$ \\
\hline
\end{tabular}

Note: In Table 2, $\mathrm{R}$ and $\mathrm{S}$ denote resistant and susceptible reactions, respectively.

\subsection{Disease Assessment and Data Analyses}

Yellow rust assessment was made 16-17 days after spraying using a 0-9 disease-scoring scale (McNeal et al., 1971). Infection types 0-6 were classified as low or resistant while 7-9 scores were considered as high or susceptible infection types (Stubbs, 1985). A race number (code) was given to each isolate according to Johnson et al. (1972) which was based on their reaction on the 'world' sets and 'European sets' of yellow rust differential lines.

A matching technique based on the gene-for-gene concept was applied to characterize seedling yellow rust resistance genes in advanced bread wheat lines and commercial cultivars (Browder, 1971; Wellings et al., 
1988). The reaction of each test genotype was compared with the reaction of the differential lines to nine individual races. Wheat genotypes which exhibited similar reaction patterns with that of specific differential lines to a range of isolates were being postulated to possess the same resistance gene(s).

\section{Results and Discussion}

The yellow rust races had combined virulence/avirulence formula to yellow rust resistance genes (Yrs); namely, 1, $2,2^{+}, 3 \mathrm{~V}, 3 \mathrm{~N}, 4^{+}, 6,6^{+}, 7,7^{+}, 8,9,9^{+}, 17, \mathrm{SD}, \mathrm{SU} / 5,10$, $15, \mathrm{CV}$ and SP (Table 1). Virulent races to $\operatorname{Yr} 5$, Yr15, $Y n C V$ and $Y r S P$ are not common in East Africa or Europe (Danial and Stubbs, 1992; Bayles and Stigwood, 2001). However, virulence for Yr10 had been reported from samples collected in central and northwestern part of Ethiopia (Ayele and Stubbs, 1995). So far, virulent races on Yrs., 2, $2^{+}, 3 N, 6,6^{+}, 7,7^{+}, 8,9,9^{+}, 10, S U, S D$ have been detected singly or in many combinations in Ethiopia (Ayele, 2002). The races used in this study exhibited broad virulence patterns that represent the common virulences reported so far from Ethiopia.

The reaction of advanced bread wheat lines and commercial cultivars to nine yellow rust races is shown in Table 2. Almost all the advanced bread wheat lines exhibited different resistance spectra when compared with that of commercial cultivars. Eleven of the advanced bread wheat lines were resistant to races 230E158 from Ethiopia whereas all the commercial cultivars exhibited susceptible ITs. The aforementioned race was detected in Arsi and Bale during 1998 and overcame the resistance of most of the bread wheat cultivars including, 'Kubsa' (Ayele, 2002). Out of 41 tested entries only 8.3.8 (B) exhibited resistance while four bread wheat cultivars (K6295-4A, ET13, 'Dereselign' and K6290-B) showed susceptible ITs to all nine races employed in this study. However, with the exception 'Derselign', the rest often show low terminal severity when compared to other susceptible cultivars at adult plant growth stage (Ayele, 2002). The bread wheat cultivars HAR1685 ('Kubsa') and HAR604 ('Galama') were susceptible to race 6E22. This race was avirulent on Federation*4/Kavkaz $(Y r 9)$ and Clement $\left.(Y r)^{+}\right)$which indicated that the aforementioned resistance gene may be absent in the two widely grown bread wheat cultivars.

The yellow rust resistance genes were postulated in some of advanced bread wheat lines and commercial cultivars (Table 3). Two of the advanced lines 11.5.39-2 and 11.6.21 were susceptible to 237E141, 232E137, 169E136, 109E141, 104E141 and 41E168 but resistant to the rest. The six races showed virulence for Vilmorin-23 which might indicate the presence of $Y r 3 \mathrm{~V}$ in the above two genotypes. In East Africa, virulent races for Yr1 and Yr3V have rarely been reported (Stubbs, 1988; Danial and Stubbs, 1992).

Three genotypes 8.3.8 (W), 11.4.16-3 and 11.6.24 were resistant to eight races but susceptible to one (169E136).
This race was different from the others because of its combined virulence on the differential line VPM1 (Yr17). Thus, resistance gene $\operatorname{Yr} 17$ was proposed in the three bread wheat genotypes. Two other genotypes 11.4.16-2 and 11.5.26-2 were susceptible to races 237E141 and 232E137 while exhibited resistance to the rest. Therefore, $\mathrm{Yr}^{+}$(Hybrid 46) and $\mathrm{Yr}^{+}{ }^{+}$(Clement) were postulated in the aforementioned genotypes. Virulence for $\mathrm{Yr} 9$ has commonly been reported but the two resistance genes $\mathrm{Yr}^{+}$and $\mathrm{Yr} 17$ are effective with regard to the prevailing races in East Africa (Danial and Stubbs, 1992; Ayele and Stubbs, 1995). Y 9 was first introduced into bread wheat from Rye through 1B/1R translocations (Zeller, 1973) and is common in CIMMYT-originated bread wheat cultivars (van Ginkel and Rajaram, 1993). However, virulence for $\operatorname{Yr} 17$ was detected recently in Europe (Bayles and Stigwood, 2001). The resistance gene was formerly introduced from Triticum ventricosa to bread wheat (Bariana and McIntosh, 1994).

The bread wheat genotype 11.5.26-2 was susceptible to 230E158, 70E150, 237E141 and 109E141 but it was resistant to the other five races. The above four races had common virulences for H. Kolben $(Y r 6)$, H. Peko $\left(Y r^{+}\right)$ and H.VII $\left(Y r 2^{+}\right)$which might indicate the presence of $\mathrm{Yr6}^{+}$and $\mathrm{Yr}^{+}$in 11.5.26-2. Another bread wheat genotype 11.4.16-1 was susceptible to $237 \mathrm{E} 141$ and 230E158. These races had common virulences for Clement $\left(Y_{r} \mathrm{O}^{+}\right)$, H. Kolben $(Y r \sigma)$ and H. Peko $\left(Y r \sigma^{+}\right)$. Therefore, $\mathrm{Yr} \mathrm{C}^{+}$and $\mathrm{Yr}^{+}$combinations were proposed in 11.4.16-1.

Two bread wheat genotypes 8.2.7 and 11.2.23 showed susceptible reaction to 237E141, 169E136 and 109E141 but exhibited resistance to the rest. The three races had common virulences for Federation*4/KVZ $(Y r 9)$ and chinese166 (Yr1). Thus, $Y r 9$ and $Y r 1$ genes were postulated in the two genotypes.

Five commercial bread wheat cultivars, HAR416, TUSIE (HAR 1407), BATU, DASHEN and GARA, exhibited similar resistance spectra. They showed low infection types to all eight races but were susceptible to 230E158. The eight races lack combined virulences for $\mathrm{Yr})^{+}$(Clement) and $\mathrm{Yr}^{+}$(Reichersberg 42). Therefore, the above resistance genes might confer yellow rust resistance in the five bread wheat cultivars.

In general, it is not advisable to release bread wheat genotypes with $\mathrm{Yr}^{+}, \mathrm{Yr}^{+}, \mathrm{Yr}^{+} \sigma^{+}$and $\mathrm{Yr} 2^{+}$unless they possess additional resistance genes conferring adult plant resistance. Some of the advanced bread wheat lines and commercial cultivars, which showed susceptible reaction at seedling stage exhibited low terminal yellow rust severities under field conditions in Ethiopia (Ayele, 2002). Such type of resistance, which slows disease development, has often been reported in the yellow rustwheat system (Ma and Singh, 1996). 
Table 3. Postulated yellow rust resistance genes in 11 bread wheat lines and five commercial cultivars after inoculation with nine races at seedling stage.

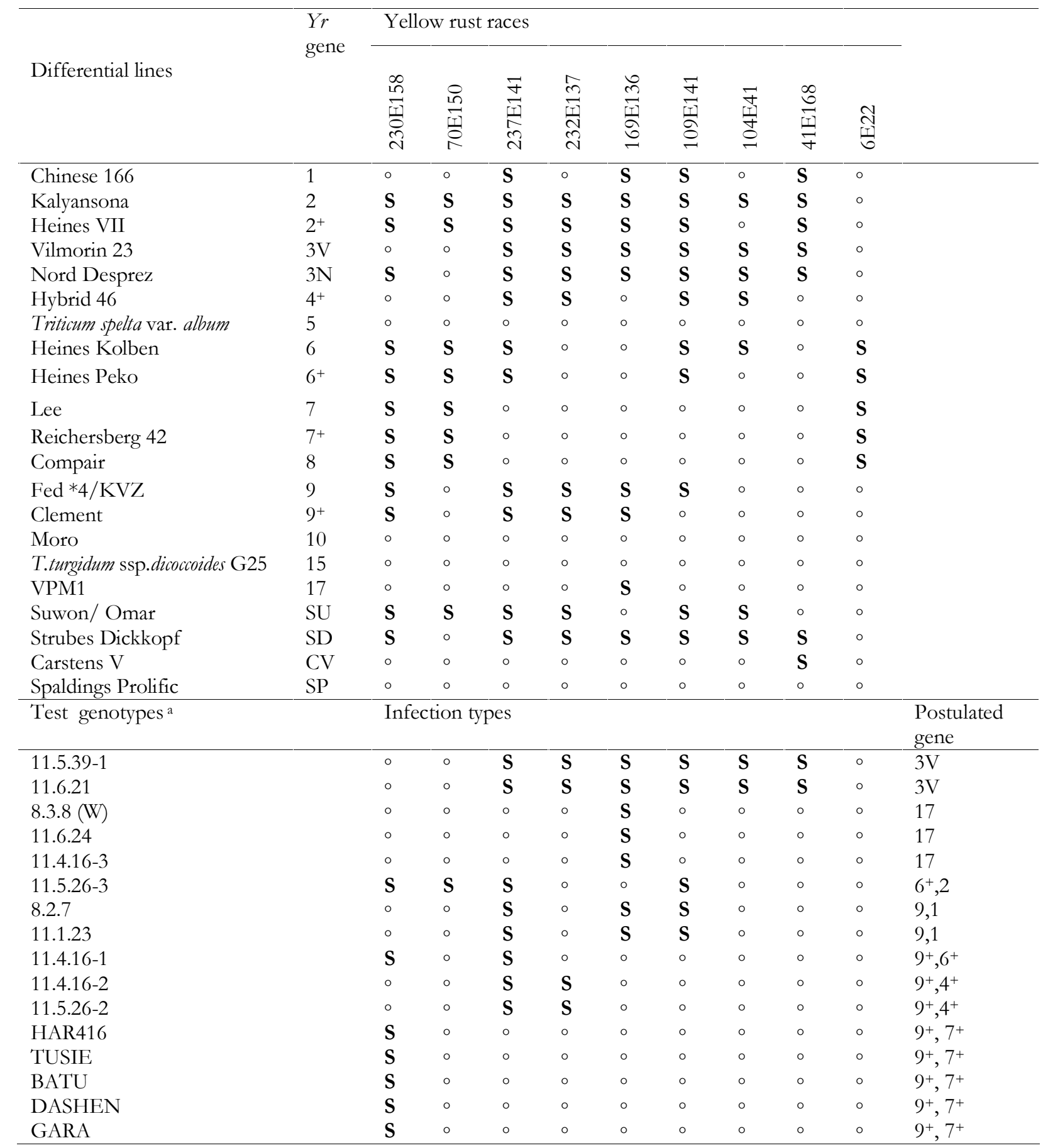

Note: in Table 3, ${ }^{\circ}$ and $S$ denote Resistance (R) and Susceptible (S) infection types, respectively.

a Source: Solomon (2001)

Breeding for disease resistance requires a comprehensive knowledge of the physiologic specialization of pathogens and the main resistance genes deployed in host genotypes before their advancement and release to the end users. The four yellow rust resistance genes $\mathrm{Yr} 1, \mathrm{Yr} 3 \mathrm{~V}, \mathrm{Yr} 4^{+}$and Yr17 identified in the nine bread wheat genotypes were different from the ones in commercial wheat cultivars from Ethiopia. Out of the advanced bread wheat genotypes, 8.3.8 (B) and 11.6.24 were released to farmers in Ethiopia, with names KBG-01 and Meraro, during 2001 and 2005 respectively. The former was resistant to the nine races and, based on $\mathrm{F}_{2}$ segregation ratio, two complementary recessive genes were postulated (data not presented). 
This study revealed that most of the advanced bread wheat lines contained different resistance spectra when compared to the commercial cultivars which appeared to lack genetic variability for resistance to the current virulent yellow rust race from Ethiopia at seedling stage. To cope with the build up of virulences, the genetic bases of resistance to yellow rust should be broadened and diversified. The advanced bread wheat lines have been identified as important sources of resistance to the prevailing races of yellow rust in Ethiopia.

\section{Acknowledgement}

The study was financed by 'Bread for the World', Stuttgart, Germany.

\section{References}

Ayele, B. 2002. Breeding bread wheat with multiple disease resistance and high yield for the Ethiopian highlands: Broadening the genetic basis of yellow rust and tan spot resistance. Ph.D Thesis. Cuvillier Verlag Goettingen, Germany. pp.115.

Ayele, B. and Stubbs, R.W. 1995. Valuable sources of resistance of wheat to the East African yellow rust isolates. In: Danial, D.L. (eds.). Breeding for disease resistance with emphasis on durability. Proceedings of a regional workshop for Eastern, Central, and Southern Africa. October 2-6, 1994. Njoro, Kenya. pp. 206-214.

Ayele, B., Stubbs, R.W., Ginkel, M. van, and Getinet, G. 1990. Identification of resistance genes to Puccinia striiformis in seedlings of Ethiopian and CIMMYT bread wheat varieties and lines. Netherlands Journal of Plant Pathology 96: 199-210.

Bariana, H.S., and McIntosh, R.A. 1994. Characterization and origin of rust and powdery mildew resistance genes in VPM1 wheat. Euphytica 76: 53-62.

Bayles, R.A., and Stigwood, P.L. 2001. Yellow rust of wheat. In: Clarkson, J.D.S. (eds.). U.K. Cereal Pathogen Virulence Survey. Annual report, 2000. Cambridge, England. pp. 28-36.

Browder, L.E. 1971. Pathogenic specialization in cereal rust fungi, especially Puccinia recondita f.sp. tritici: Concepts, methods of study and application. U.S.Dep. Agric. Tech. Bull (United States Department of Agriculture Technical Bulletin). No. 1432.

Danial, D.L., and Stubbs, R.W. 1992. Virulence of yellow rust races and types of resistance in wheat cultivars in Kenya. In: Tanner, D.G., and Mwangi, W. (eds.). Seventh Regional Wheat Workshop for Eastern, Central, and Southern Africa. September 16-19, 1991. Nakuru, Kenya: CIMMY'T. pp.165-175.

Eshetu, B. 1986. A review of research on diseases of barley, tef, and wheat in Ethiopia. In: Tsedeke, A. (eds.). A review of crop protection research in Ethiopia. Proceedings of the first Ethiopian Crop Protection Symposium. 4-7 February, 1985. Addis Ababa, Ethiopia. pp. 79-108.
Flor, H.H. 1971. Current status of the gene-for-gene concept. Annual Review of Phytopathol 9: 275-296.

Hailu, G. M. 1991. Bread wheat breeding and genetics research in Ethiopia. In: Hailu, G. M., Tanner, D.G., and Mengistu, H. (eds.). Wheat research in Ethiopia: a historical perspective. Addis Ababa. IAR/CIMMYT. pp. 73-93.

Johnson, R., Stubbs, R.W., Fuchs, E., and Chamberlain, N.H. 1972. Nomenclature for physiologic races of Puccinia striiformis infecting wheat. Transactions of British Mycological Society 58: 475-480.

http://wheat.pw.usda.gov. Catalogue of gene symbols for wheat.

Kema, G.H.J., and Lange, W. 1992. Resistance in spelt wheat to yellow rust. II. Monosomic analysis of the Iranian accession 415. Euphytica 63: 219-224.

Ma, H., and Singh, R.P. 1996. Expression of adult plant resistance to stripe rust at different growth stages of wheat. Plant Disease 80: 375-379.

McNeal, F.H., Konzak, C.F., Smith, E.P., Tate, W.S., and Russel, T.S. 1971. A uniform system for recording and processing cereal research data. United States Department of Agricultural Research Services, ARS 34-121. pp.42.

Solomon, A. 2001. Exploiting alien resistance genes in Aegilops tauschii and their utilization for the development of bread wheat genotypes with multiple resistance to major diseases. Ph.D. Thesis. Institute of Plant Pathology and Plant Protection, GeorgAugust University, Goettingen, Germany. pp.105.

Stubbs, R.W. 1985. Stripe rust. In: Roelfs, A.P. and Bushnell, W.R. (eds.). The Cereal Rusts. Volume II.. Diseases, distribution, epidemiology, and control. Academic Press, New York. pp. 61-101.

Stubbs, R.W. 1988. Pathogenicity analysis of yellow (stripe) rust of wheat and its significance in a global context. In: Simmonds, N.W. and Rajaram, S. (eds.). Breeding strategies for resistance to the rusts of wheat. CIMMYT, Mexico. pp. 23-38.

van Ginkel, M., and Rajaram, S. 1993. Breeding for durable resistance to diseases in wheat: An international perspective. In: Jacobs, T. and Parlevliet, J.E. (eds.). Durability of Disease Resistance. Wageningen, The Nether lands. pp. 259272.

Wellings, C.R., and McIntosh, R.A. 1990. Puccinia striiformis $\mathrm{f}$. $\mathrm{sp}$. tritici in Australasia: pathogenic changes during the first 10 years. Plant Pathology 39: 316-325.

Wellings, C.R., McIntosh, R.A., and Hussain, M. 1988. A new source of resistance to Puccinia striiformis f.sp. tritici in spring wheat (Triticum aestivum). Plant Breeding 100: 88-96.

Zadoks, J.C. 1961. Yellow rust on wheat: Studies in epidemiology and physiologic specialization. Netherlands Journal of Plant Pathology 67:69-256.

Zeller, F.J. 1973. 1B/1R wheat-rye chromosome substitutions and translocations. Proceedings of the Fourth International Wheat Genetics Symposium. Columbia. pp. 209-222. 

